\title{
Factors Affecting the Choice of Career amongst the Postgraduate Scholars of Agricultural Extension
}

\author{
G. Naveen Kumar ${ }^{*}$ and N. B. Chauhan ${ }^{2}$ \\ Department of Agricultural Extension and Communication, B. A. College of Agriculture, \\ Anand Agricultural University, Anand, India \\ *Corresponding author
}

\begin{abstract}
A B S T R A C T
Job preference is the interest of the respondents about their linking and desire to do job permanently with full confidence and satisfactorily after completing their education. This variable was measured in term of type of job preferred by the respondents. The present study was carried out in Anand Agricultural University in the year 2019-20. For this study, the list of postgraduate scholars those who are pursuing postgraduation in agricultural extension from all the four SAUs of Gujarat were taken and from that a total of 120 postgraduate scholars were selected randomly for the present study. The result indicates that the most preferred job of the postgraduate scholars studying in extension education was working with state department of agriculture, followed by academic or teaching, agricultural research, agricultural entrepreneurship, banking sector, agri-input dealership, agricultural marketing, agricultural consultancy, administrative or managerial job, agricultural journalism, cooperative society, working with NGOs and establishment of own NGO. It was also seen that little less preferred job was to join forest department. Correlation analysis revealed that mothers' education, achievement motivation, innovativeness and willingness to work in rural areas had positive association with job preference of postgraduate scholars of agricultural extension. Job preference of postgraduate scholars was found to be predicted by two variables willingness to work in rural area and achievement motivation which have together contributed 65.90 variations on their job preference.
\end{abstract}

Keywords

Job preference,

Postgraduate,

Agricultural

Extension,

Occupation, Career

choice, SDA

Article Info

Accepted:

15 September 2020

Available Online:

10 October 2020

\section{Introduction}

The job preference is choice of person to select profession as livelihood. It is the most important aspect in the life of any students to get expected degree of satisfaction and happiness in the life. Occupation plays an important role in the life of an individual. Thus those in the education process develop awareness towards the type of education imparted and the courses in which they are enrolled. It helps them in judging their future prospectus and scope for employment (Bhosale, 2011). The recent technological advancement in agricultural research and agricultural production sector have considerably enlarged the scope of agricultural graduates and consequently 
resulted in several new job opportunities for degree holders in agriculture. At present a large variety and different types of jobs are available for the agricultural graduates .It is well known that individuals, who make job preference or career choice based on personal interests and abilities, get significantly higher levels of job satisfaction and are proved as more productive workers. It is assumed that, the postgraduate scholars who choose their job preference wisely will influence their extension employability. Considering this, the present study was conducted amongst postgraduate scholars of agricultural extension to know the factors affecting their job preference.

\section{Materials and Methods}

It is the interest of the respondents about their linking and desire to do job permanently with full confidence and satisfactorily after completing their education. This variable was measured in term of type of job preferred by the respondents. A list of 14 jobs were identified viz. academic or teaching, entrepreneurship, marketing, research and development department, agricultural journalism, bank, cooperative society, consultancy, non-government organizations and non-agricultural professions. The responses were collected in three continuums as mostly preferred, rarely preferred and never preferred and scores of two, one and zero were assigned for each job. Total score was worked out by summing all the scores for all the preferred jobs to quantify job preference. Thereafter mean score for each preferred job was worked out and ranked as per the mean scores (Sasidharan, 2013). Coefficient of correlation was computed to find out the relationship between the independent and dependent variables. The step-wise regression (multiple regressions) analysis was employed to predict the extent of extension employability by independent variables.

\section{Results and Discussion}

\section{Job preference of postgraduate scholars}

The results seen in the Table 1 indicates that the most preferred job of the postgraduate scholars studying in extension education was working with state department of agriculture, followed by academic or teaching, agricultural research, agricultural entrepreneurship, banking sector, agri-input dealership, agricultural marketing, agricultural consultancy, administrative or managerial job, agricultural journalism, cooperative society, working with NGOs and establishment of own NGO. It was also seen that little less preferred job was to join forest department. It can be concluded from the Table 1 that the first three choices of the postgraduates of extension education were working with state department of agriculture as extension service provider, academic or teaching and agricultural research. The most desired preference was to join SDAs perceived brighter job opportunities due to regular recruitment in state department of agriculture. On the other hand, next to their most preferred career options were to be academic teacher and researcher because of self-esteem and respectable profession with high remuneration.

The entrepreneurship was also regarded as one of the most preferred choices of the postgraduate scholars, because ICAR has recently launched Student READY (Rural Entrepreneurship Awareness Development Yojana) and ELP (Experiential Learning Programmes) to provide rural entrepreneurship awareness, practical life experience to develop much needed skills and entrepreneurial mind set among the postgraduate scholars to take up selfemployment. The findings of the present study clearly envisage that employment in government organisations was the most 
preferred option of job shown by the postgraduate scholars. This might be due to the fact that majority of the postgraduate scholars were from rural background and had dream to serve in government organization which has wider reputation in the society. The results were in line with the findings of Sashidharan (2013) and Vegad (2020).

$\begin{array}{lll}\text { Relationship between } & \text { the profile of } \\ \text { postgraduate } & \text { scholars and their job } \\ \text { preference } & & \end{array}$

From the table 2 it can be observed that the choice of career amongst postgraduate scholars was observed similar with irrespective level of their academic performance, gender, medium of instruction at school level, fathers education, type of family, size of family, to the caste they belong, annual family income, family occupation family land holding, type of native, involvement in extracurricular activities, time spent in rural area and library exposure.

The result indicates that the postgraduate scholars with regardless of some of their selected personal, social, economic, situational and communicational characteristics had understood similar level of significance of developing wide range of interest to be a part of many probable professions as livelihood. The perception of wide competition and difficulty in the present scenario in getting various jobs in country might have motivated them to make them mentally prepared to go for variety of job as livelihood career.

\section{Mothers' education and job preference}

Mother is the first teacher of children in the world. She is the sculptor of child's behaviour, attitude, thinking, and character. They are the ones who have regular interactions with the children and understanding about their ambitions, dreams and aspirations. The postgraduate scholars with educated mothers had good awareness about the development of necessary knowledge, skills and attitude required to be employable in this competitive era. Such awareness of mothers might have motivated their children to acquire knowledge and skills to choose diversified jobs as their career options. The result was in line with the findings of Bhosale (2011).

\section{Achievement motivation and job preference}

It was observed from the table 2 that postgraduate scholars with higher levels of achievement motivation had better career preferences. Scholars with higher levels of achievement motivation aspire for better careers in order to excel in life. The highly motivated people can aim high to achieve better careers for bringing improvements in their living standards which led to the positive association of achievement motivation with their choice of career. The result was in line with the findings of Krishna et al., (2017).

\section{Innovativeness and job preference}

Innovativeness is the vital quality for surviving in the work place. The postgraduate scholars with high innovativeness might have understood the significance of developing critical thinking ability, creative thinking nature and ability to use of the resources available. Such situation might have played a positive role in the choice of career to be a part of diversified jobs. The course curriculum of agricultural extension with practical exposure to various situations and motivation from the teachers to express their views and ideas might have led them to develop and have wide range of interest to choose diversified jobs. 
Table.1 Postgraduate scholars according to their job preference $n=120$

\begin{tabular}{|c|l|c|c|}
\hline & & & \\
\hline No & Type of Job & Mean value & Rank \\
\hline $\mathbf{1}$ & State Department of Agriculture (SDA) & 1.78 & $1^{\text {st }}$ \\
\hline $\mathbf{2}$ & Academic teaching & 1.75 & $2^{\text {nd }}$ \\
\hline $\mathbf{3}$ & Agricultural research & 1.47 & $3^{\text {rd }}$ \\
\hline $\mathbf{4}$ & Agricultural entrepreneurship & 1.36 & $4^{\text {th }}$ \\
\hline $\mathbf{5}$ & Banking sector & 1.29 & $5^{\text {th }}$ \\
\hline $\mathbf{6}$ & Agri-input dealership & 1.19 & $6^{\text {th }}$ \\
\hline $\mathbf{7}$ & Agricultural marketing & 1.13 & $7^{\text {th }}$ \\
\hline $\mathbf{8}$ & Agricultural consultancy & 1.05 & $8^{\text {th }}$ \\
\hline $\mathbf{9}$ & Administrative / Managerial & 1.04 & $9^{\text {th }}$ \\
\hline $\mathbf{1 0}$ & Agricultural journalism & 1.03 & $10^{\text {th }}$ \\
\hline $\mathbf{1 1}$ & Cooperative society & 0.98 & $11^{\text {th }}$ \\
\hline $\mathbf{1 2}$ & NGOs & 0.97 & $12^{\text {th }}$ \\
\hline $\mathbf{1 3}$ & Establishment of own NGO & 0.96 & $13^{\text {th }}$ \\
\hline $\mathbf{1 4}$ & Forest department & 0.88 & $14^{\text {th }}$ \\
\hline & & & \\
\hline
\end{tabular}

Table.2 Relationship between the profile of postgraduate scholars and their job preference $\mathrm{n}=120$

\begin{tabular}{|c|l|c|}
\hline \multicolumn{2}{|c|}{\begin{tabular}{c} 
Independent Variables \\
\hline No
\end{tabular}} & Correlation Coefficient (r) \\
\hline $\mathbf{A}$ & Personal variables & -0.073 \\
\hline $\mathbf{1}$ & Academic performance & 0.067 \\
\hline $\mathbf{2}$ & Gender & 0.112 \\
\hline $\mathbf{3}$ & Medium of instruction at school level & 0.038 \\
\hline $\mathbf{4}$ & Fathers education & $0.219^{*}$ \\
\hline $\mathbf{5}$ & Mothers education & -0.002 \\
\hline $\mathbf{B}$ & Social variables & -0.043 \\
\hline $\mathbf{6}$ & Type of family & -0.077 \\
\hline $\mathbf{7}$ & Size of family & \\
\hline $\mathbf{8}$ & Caste & 0.125 \\
\hline $\mathbf{C}$ & Economic variables & 0.042 \\
\hline $\mathbf{9}$ & Annual family income & -0.012 \\
\hline $\mathbf{1 0}$ & Family occupation & \\
\hline $\mathbf{1 1}$ & Family land holding & -0.028 \\
\hline $\mathbf{D}$ & Situational and communicational variables & 0.109 \\
\hline $\mathbf{1 2}$ & Native & 0.064 \\
\hline $\mathbf{1 3}$ & Involvement in extracurricular activities & 0.010 \\
\hline $\mathbf{1 4}$ & Time spent in rural area & \\
\hline $\mathbf{1 5}$ & Library exposure & $0.340^{* *}$ \\
\hline $\mathbf{E}$ & Psychological variables & $0.319^{* *}$ \\
\hline $\mathbf{1 6}$ & Achievement motivation & $0.793^{* *}$ \\
\hline $\mathbf{1 7}$ & Innovativeness & \\
\hline $\mathbf{1 8}$ & Willingness to work in rural area & \\
\hline & & \\
\hline
\end{tabular}

* Significant at 0.05 level of probability $\quad$ ** Significant at 0.01 level of probability 
Table.3 Step-wise regression analysis for the extension employability of postgraduate scholars

$$
\mathrm{n}=120
$$

\begin{tabular}{|c|c|c|c|c|c|c|}
\hline No & $\begin{array}{c}\text { Independent } \\
\text { variable }\end{array}$ & $\begin{array}{c}\text { Partial } \\
\text { regression } \\
\text { coefficient }\end{array}$ & $\begin{array}{c}\text { Standard error of } \\
\text { partial regression } \\
\text { coefficient }\end{array}$ & $\begin{array}{c}\text { 't' } \\
\text { value }\end{array}$ & $\begin{array}{c}\text { Standard } \\
\text { partial } \\
\text { regression } \\
\text { coefficient }\end{array}$ & Rank \\
\hline 1 & $\begin{array}{l}\text { Willingness to work } \\
\text { in rural area }\end{array}$ & $0.552 * *$ & 0.040 & 13.671 & 0.927 & I \\
\hline 2 & $\begin{array}{l}\text { Achievement } \\
\text { motivation }\end{array}$ & $0.332 * *$ & 0.101 & 3.273 & 0.222 & II \\
\hline
\end{tabular}

** Significant at 0.01 level of probability

$$
\mathrm{R}^{2}=65.90 \% \quad \mathrm{df}=2
$$

Willingness to work in rural areas and job preference

From the table 2 it can be observed that there is a positive relationship between willingness to work in rural areas with their job preference. It is natural that a person with higher level of willingness to work in rural areas had diversified interest of career options, as most of the agricultural related jobs were in the rural areas. Majority of the postgraduate scholars had rural native with agricultural and allied activities as their income generating activity. The parents of postgraduate scholars might have motivated and trained their mind set of children to work in rural areas, led to the positive relationship of willingness to work in rural areas with their job preference

\section{Extent of relationship between independent variables and job preference}

The stepwise regression analysis suggests that the regression coefficients such as willingness to work in rural area and achievement motivation were found to be highly significant. The $\mathrm{R}^{2}$ value is 0.659 , which indicates about 65.90 per cent predication of dependent variable through the set of independents variables listed in above table. The independent variables were ranked on the basis of standard partial regression coefficient values to find out their relative important in predicting the dependent variable. The table 3 indicates rank order it is as, willingness to work in rural area (Rank-I), and achievement motivation (Rank-II) were ranked first and second. The findings suggested that to improve the choices of postgraduate scholars to be employable and to be a part of multiple jobs, the variables such as achievement motivation and willingness to work in rural areas should be emphasized.

From the results it can be concluded that the most preferred job of majority of postgraduate scholars studying in extension education was state department of agriculture, followed by academic or teaching, agricultural research and agricultural entrepreneurship. The career choice amongst postgraduate scholars studying in extension education was majorly explained by two variables achievement motivation and willingness to work in rural areas. The level of career choice was observed wider amongst those postgraduates, who had highly educated mothers, high level of achievement motivation, innovativeness and elevated willingness to work in rural areas. Hence the policy makers should concentrate to provide more motivational aspects to inculcate positive inclination to work in rural areas and to be successful in their careers. 


\section{References}

Bhosale, S. (2011). Occupational Aspiration of Postgraduate Agriculture Students of Anand Agricultural University, Anand (M.Sc. (Agri.) thesis, AAU, Anand).

Sashidharan, D. (2013). Employability of postgraduate scholars studying in higher agriculture education (M.Sc. (Agri.) thesis, AAU, Anand).

Vegad, N. (2020). E-extension employability amongst postgraduate scholars of
SAUs of Gujarat (Ph.D. thesis, AAU, Anand).

Krishna, B., Sharma, G.R.K., Harilal, R., and Suresh, J. (2017).Relationship between achievement motivation and risk preference with career preferences of veterinary students in Andhra Pradesh. International Journal of Science, Environment and Technology, Vol. $6(3): 1985-88$

\section{How to cite this article:}

Naveen Kumar, G. and Chauhan, N. B. 2020. Factors Affecting the Choice of Career amongst the Postgraduate Scholars of Agricultural Extension. Int.J.Curr.Microbiol.App.Sci. 9(10): 1938-1943. doi: https://doi.org/10.20546/ijcmas.2020.910.237 